\title{
Responses of Dry Bean to Biostimulants Added to Postemergence Herbicides
}

\author{
Nader Soltani*, Christy Shropshire, Peter H. Sikkema \\ University of Guelph Ridgetown Campus, Ridgetown, Canada \\ Email: soltanin@uoguelph.ca
}

Received 27 August 2015; accepted 20 September 2015; published 23 September 2015

Copyright (C) 2015 by authors and Scientific Research Publishing Inc.

This work is licensed under the Creative Commons Attribution International License (CC BY). http://creativecommons.org/licenses/by/4.0/

c) (i) Open Access

\section{Abstract}

The effect of biostimulants such as Crop Booster and RR SoyBooster on dry bean under Ontario environmental conditions is not known. A total of 12 field experiments ( 6 in cranberry bean "Etna" and 6 in white bean "OAC REX") were conducted at two locations (Ridgetown and Exeter, Ontario, Canada) to evaluate the effect of Crop Booster and RR SoyBooster on visible injury, shoot dry weight, height and yield of cranberry and white bean. Visible injury ranged from $0 \%$ to $7.3 \%$ in white bean and $0 \%$ to $9.4 \%$ in cranberry bean with quizalofop-p-ethyl, bentazon, fomesafen, bentazon plus fomesafen, imazethapyr and imazethapyr plus bentazon alone or in combination with Crop Booster and RR SoyBooster. The addition of Crop Booster or RR SoyBooster to herbicides evaluated had no significant effect on shoot dry weight, height, seed moisture content and yield of white or cranberry bean except with the addition of RR SoyBooster to quizalofop-p-ethyl which increased height 3.7\% and the addition of the Crop Booster to bentazon which decreased shoot dry weight $12 \%$ and the addition of Crop Booster to bentazon plus fomesafen which increased shoot dry weight $17 \%$ in white bean. Based on these results, there were minimal effects from the addition of Crop Booster or RR SoyBooster to commonly used herbicides in white and cranberry bean.

\section{Keywords}

Cranberry Bean, Injury, Height, Herbicide, Tolerance, White Bean, Yield

\section{Introduction}

Dry bean (Phaseolus vulgaris L.) is a high value leguminous crop with nitrogen fixation ability that Ontario growers often use in rotation with wheat (Triticum aestivum L.), field corn (Zea mays L.) and soybean [Glycine

\footnotetext{
"Corresponding author.
} 
$\max$ (L.) Merr.] to break pest cycles and improve soil fertility. In 2014, dry bean growers planted nearly 53,000 hectares and produced 130,000 MT of dry bean with a farm gate value of approximately \$100,000,000 [1]. Major market classes (different geographic origin, gene pool, seed size and seed color) of dry bean grown in Ontario include black, cranberry, kidney and white (navy) bean. Intensive agronomic practices, including proper weed management and plant nutrition, are needed for profitable dry bean production.

In recent years, biostimulants have been marketed by agricultural products companies for enhancing crop growth and yield of various crops. Biostimulants are generally referred to as compounds, substances and other products that can enhance plant growth and development by increasing the efficiency of physiological process within plants when applied in small quantities to plants or soils [2] [3]. These products can include microorganisms, trace elements, enzymes or plant growth regulators [2] [3]. Biostimulant global market is projected to grow 12.5\% annually and reach US\$ 2241 million by 2018 [3]. Research has shown the ability of some biostimulants to enhance crop efficiency, increase nutrient availability, increase water-holding capacity, increase antioxidants, enhance metabolism and increase chlorophyll production in plants [3]-[10]. Hanson [7] found significant increases in yield of vegetable crops with biostimulants. Al-Majathoub [10] found as much as $21 \%$ increase in tiller numbers and as much as $8.2 \%$ increase in wheat yield with biostimulants.

Crop Booster and RR SoyBooster are two biostimulants marketed by Axter Agrosciences Inc. for enhancing vigor and foliage development in fruits, vegetables and field crops in Ontario [11]-[13]. Crop Booster contains $15 \%$ total nitrogen, $3 \%$ phosphoric acid $\left(\mathrm{P}_{2} \mathrm{O}_{5}\right)$, $6 \%$ soluble potash $\left(\mathrm{K}_{2} \mathrm{O}\right), 0.02 \%$ boron, $0.05 \%$ chelated manganese, $0.05 \%$ molybdenum, $0.05 \%$ chelated zinc, and 0.5\% E.D.T.A. (chelating agent) [12]. RR SoyBooster composition is exactly the same as Crop Booster except for its total nitrogen which is $6 \%$ and available phosphoric acid $\left(\mathrm{P}_{2} \mathrm{O}_{5}\right)$ which is $18 \%$ [13].

According to the Axter Agrosciences Inc., Crop Booster enables plants to produce the enzymes and organic acid needed to combat stress and compensate for plant's inability to take up nutrients from the soil during periods of crop stress [11]. Crop Booster is also promoted as a biostimulant that works synergistically with herbicides to decrease crop stress that may be caused by the use of postemergence herbicides [11].

Dry bean growers need information on the effect of biostimulants such as Crop Booster and RR SoyBooster on crop growth, development and weed control to make informed decisions on their use in order to maximize farm profitability as the demand on growers to minimize per unit cost of production is increasing to remain competitive in the global market. Lack of information or incorrect information about biostimulants may lead to unnecessary expenditures, and/or costly risk of failures in crop production including unnecessary loading of chemicals in the environment.

There is little information on the effects of the co-application of Crop Booster or RR SoyBooster with quizalofop-p-ethyl, bentazon, fomesafen, bentazon plus fomesafen, imazethapyr and imazethapyr plus bentazon in cranberry and white bean under Ontario environmental conditions.

The objective of this study was to evaluate if there was any benefit of adding Crop Booster or RR SoyBooster to postemergence herbicides that were commonly used for weed management in white and cranberry bean.

\section{Materials and Methods}

There were a total of 12 field experiments ( 6 in cranberry bean "Etna" and 6 in white bean "OAC REX") conducted during 2006 to 2008 at the Huron Research Station, Exeter, Ontario and University of Guelph Ridgetown Campus, Ridgetown, Ontario. The soil type at Exeter was a Brookston clay loam soil and at Ridgetown was a Brookston loam soil. Seedbed preparation at all sites consisted of fall moldboard plowing followed by two passes with a field cultivator with rolling basket harrows in the spring.

Field trials were established as a randomized complete block design with four replications. Treatments are listed in Tables 1-12 for white bean and cranberry trials. Plots consisted of two rows of cranberry bean ("Etna") or white bean ("OAC REX") that were spaced $0.75 \mathrm{~m}$ apart and were $10 \mathrm{~m}$ long at Exeter and $8 \mathrm{~m}$ long at Ridgetown. Beans were planted in late May to early June of each year. Dry beans were fertilized according to provincial recommendations [1]. Dry beans are not generally irrigated in Ontario.

Herbicide treatments were applied with a $\mathrm{CO}_{2}$-pressurized back-pack sprayer equipped with Hypro ULD12002 nozzle tips (Hypro, New Brighton, MN) calibrated to deliver $200 \mathrm{~L} \cdot h a^{-1}$ of water at $200 \mathrm{kPa}$. Herbicide applications were made with a $2.5 \mathrm{~m}$ boom with six nozzles spaced $50 \mathrm{~cm}$ apart. Treatments were applied when the beans were in the 1 - 3 trifoliate leaf stage. All plots were maintained weed-free during the season with hand 
Table 1. Comparison of visible white bean injury 1, 2 and 4 WAT, dry weight 4 WAT, height 7 WAT, moisture at harvest and yield for quizalofop-p-ethyl alone vs quizalofop-p-ethyl plus Crop Booster or RR SoyBooster. Values for the weed-free check were not included in the analysis ${ }^{\mathrm{a}}$.

\begin{tabular}{|c|c|c|c|c|c|c|c|c|}
\hline \multirow{3}{*}{ Treatment $^{\mathrm{b}}$} & \multicolumn{5}{|c|}{ Injury } & \multirow[b]{2}{*}{ Height } & \multirow[b]{2}{*}{ Moisture } & \multirow[b]{2}{*}{ Yield } \\
\hline & Rate & $1 \mathrm{WAT}$ & 2 WAT & 4 WAT & Dry weight & & & \\
\hline & $\begin{array}{l}\text { g ai ha }{ }^{-1} \text { or } \\
\text { L } \cdot a^{-1}\end{array}$ & & $\%$ & & $\mathrm{~g} \cdot \mathrm{m}^{-1}$ row & $\mathrm{cm}$ & $\%$ & MT ha $^{-1}$ \\
\hline Weed-free check & & 0.0 & 0.0 & 0.0 & 218 & 53.8 & 17.9 & 2.65 \\
\hline Quizalofop-p-ethyl & $72 \mathrm{~g}$ & 2.2 & 0.4 & 0.1 & 213 & 54.2 & 17.7 & 2.53 \\
\hline $\begin{array}{c}\text { Quizalofop-p-ethyl + Crop } \\
\text { Booster }\end{array}$ & $72 \mathrm{~g}+2 \mathrm{~L}$ & 2.5 & 0.4 & 0.0 & 228 & 54.2 & 18.0 & 2.67 \\
\hline $\begin{array}{l}\text { Quizalofop-p-ethyl + RR } \\
\text { SoyBooster }\end{array}$ & $72 \mathrm{~g}+2 \mathrm{~L}$ & 2.1 & 0.5 & 0.0 & 222 & $56.2^{*}$ & 18.1 & 2.70 \\
\hline
\end{tabular}

${ }^{\text {a }}$ Significance of contrasts comparing quizalofop-p-ethyl alone with quizalofop-p-ethyl plus either Crop Booster or RR SoyBooster denoted by ${ }^{*}$ for P $<$ 0.10 and ${ }^{* *}$ for $\mathrm{P}<0.05$ beside the respective mean. ${ }^{\mathrm{b}}$ Sure-mix added to all herbicide treatments at $0.5 \% \mathrm{v} / \mathrm{v}$.

Table 2. Comparison of visible cranberry bean injury 1, 2 and 4 WAT, dry weight 4 WAT, height 7 WAT, moisture at harvest and yield for quizalofop-p-ethyl alone vs quizalofop-p-ethyl plus Crop Booster or RR SoyBooster. Values for the weed-free check were not included in the analysis ${ }^{\mathrm{a}}$.

\begin{tabular}{|c|c|c|c|c|c|c|c|c|}
\hline \multirow{3}{*}{ Treatment $^{\mathrm{b}}$} & \multicolumn{5}{|c|}{ Injury } & \multirow[b]{2}{*}{ Height } & \multirow[b]{2}{*}{ Moisture } & \multirow[b]{2}{*}{ Yield } \\
\hline & Rate & $1 \mathrm{WAT}$ & 2 WAT & 4 WAT & Dry weight & & & \\
\hline & $\begin{array}{l}\text { g ai ha }{ }^{-1} \text { or } \\
\text { L } \cdot \mathrm{ha}^{-1}\end{array}$ & & $\%$ & & $\mathrm{~g} \cdot \mathrm{m}^{-1}$ row & $\mathrm{cm}$ & $\%$ & MT ha ${ }^{-1}$ \\
\hline Weed-free check & & 0.0 & 0.0 & 0.0 & 231 & 50.1 & 16.6 & 2.40 \\
\hline Quizalofop-p-ethyl & $72 \mathrm{~g}$ & 2.1 & 0.6 & 0.2 & 233 & 50.0 & 16.4 & 2.22 \\
\hline $\begin{array}{c}\text { Quizalofop-p-ethyl + Crop } \\
\text { Booster }\end{array}$ & $72 \mathrm{~g}+2 \mathrm{~L}$ & 2.4 & 0.9 & 0.3 & 240 & 50.0 & 16.6 & 2.31 \\
\hline $\begin{array}{l}\text { Quizalofop-p-ethyl + RR } \\
\text { SoyBooster }\end{array}$ & $72 g+2 L$ & 2.3 & 0.7 & 0.2 & 231 & 51.4 & 16.9 & 2.33 \\
\hline
\end{tabular}

${ }^{a}$ Significance of contrasts comparing quizalofop-p-ethyl alone with quizalofop-p-ethyl plus either Crop Booster or RR SoyBooster denoted by ${ }^{*}$ for $\mathrm{P}$ $<0.10$ and ${ }^{* *}$ for $\mathrm{P}<0.05$ beside the respective mean. ${ }^{\mathrm{b}}$ Sure-mix added to all herbicide treatments at $0.5 \% \mathrm{v} / \mathrm{v}$.

Table 3. Comparison of visible white bean injury 1, 2 and 4 WAT, dry weight 4 WAT, height 7 WAT, moisture at harvest and yield for bentazon alone vs bentazon plus Crop Booster or RR SoyBooster. Values for the weed-free check were not included in the analysis ${ }^{\mathrm{a}}$.

\begin{tabular}{|c|c|c|c|c|c|c|c|c|}
\hline \multirow{3}{*}{ Treatment } & \multicolumn{4}{|c|}{ Injury } & \multirow[b]{2}{*}{ Dry weight } & \multirow[b]{2}{*}{ Height } & \multirow[b]{2}{*}{ Moisture } & \multirow[b]{2}{*}{ Yield } \\
\hline & Rate & $\begin{array}{c}1 \\
\text { WAT }\end{array}$ & $\begin{array}{c}2 \\
\text { WAT }\end{array}$ & $\begin{array}{c}4 \\
\text { WAT }\end{array}$ & & & & \\
\hline & g ai ha ${ }^{-1}$ or $L \cdot h^{-1}$ & & $\%$ & & $\mathrm{~g} \cdot \mathrm{m}^{-1}$ row & $\mathrm{cm}$ & $\%$ & MT ha $^{-1}$ \\
\hline Weed-free check & & 0.0 & 0.0 & 0.0 & 218 & 53.8 & 17.9 & 2.65 \\
\hline Bentazon & $1080 \mathrm{~g}$ & 1.9 & 0.1 & 0.0 & 212 & 54.4 & 17.8 & 2.58 \\
\hline Bentazon + Crop Booster & $1080 \mathrm{~g}+2 \mathrm{~L}$ & 2.4 & 0.1 & 0.0 & $186^{* *}$ & 54.1 & 17.8 & 2.68 \\
\hline Bentazon + RR SoyBooster & $1080 \mathrm{~g}+2 \mathrm{~L}$ & 2.9 & 0.2 & 0.0 & 222 & 54.9 & 18.2 & 2.71 \\
\hline
\end{tabular}

${ }^{\mathrm{a}}$ Significance of contrasts comparing bentazon alone with bentazon plus either Crop Booster or RR SoyBooster denoted by ${ }^{*}$ for $\mathrm{P}<0.10$ and ${ }^{* * *}$ for $\mathrm{P}<$ 0.05 beside the respective mean.

hoeing and cultivation as required.

Estimate of crop injury was evaluated visually 1, 2 and 4 weeks after treatment (WAT) using a scale of 0 to $100 \%$ where a rating of 0 was defined as no visible plant injury and a rating of 100 was defined as plant death. 
Table 4. Comparison of visible cranberry bean injury 1, 2 and 4 WAT, dry weight 4 WAT, height 7 WAT, moisture at harvest and yield for bentazon alone vs bentazon plus Crop Booster or RR SoyBooster. Values for the weed-free check were not included in the analysis ${ }^{\mathrm{a}}$.

\begin{tabular}{|c|c|c|c|c|c|c|c|c|}
\hline \multirow{3}{*}{ Treatment } & \multicolumn{6}{|c|}{ Injury } & \multirow[b]{2}{*}{ Moisture } & \multirow[b]{2}{*}{ Yield } \\
\hline & Rate & $1 \mathrm{WAT}$ & 2 WAT & 4 WAT & Dry weight & Height & & \\
\hline & g ai ha ${ }^{-1}$ or $L \cdot h a^{-1}$ & & $\%$ & & $\mathrm{~g} \cdot \mathrm{m}^{-1}$ row & $\mathrm{cm}$ & $\%$ & MT ha $^{-1}$ \\
\hline Weed-free check & & 0.0 & 0.0 & 0.0 & 231 & 50.1 & 16.6 & 2.40 \\
\hline Bentazon & $1080 \mathrm{~g}$ & 2.8 & 1.0 & 0.0 & 217 & 49.3 & 16.9 & 2.27 \\
\hline Bentazon + Crop Booster & $1080 g+2 L$ & 3.4 & 1.0 & 0.0 & 220 & 50.5 & 16.8 & 2.36 \\
\hline Bentazon + RR SoyBooster & $1080 g+2 L$ & 3.5 & 1.0 & 0.0 & 210 & 49.5 & 16.6 & 2.32 \\
\hline
\end{tabular}

${ }^{\mathrm{a}}$ Significance of contrasts comparing bentazon alone with bentazon plus either Crop Booster or RR SoyBooster denoted by ${ }^{*}$ for $\mathrm{P}<0.10$ and ${ }^{* *}$ for $\mathrm{P}<$ 0.05 beside the respective mean.

Table 5. Comparison of visible white bean injury 1, 2 and 4 WAT, dry weight 4 WAT, height 7 WAT, moisture at harvest and yield for fomesafen alone vs fomesafen plus Crop Booster or RR SoyBooster. Values for the weed-free check were not included in the analysis ${ }^{\mathrm{a}}$.

\begin{tabular}{|c|c|c|c|c|c|c|c|c|}
\hline \multirow{3}{*}{ Treatment $^{\mathrm{b}}$} & \multicolumn{6}{|c|}{ Injury } & \multirow[b]{2}{*}{ Moisture } & \multirow[b]{2}{*}{ Yield } \\
\hline & Rate & 1 WAT & 2 WAT & 4 WAT & Dry weight & Height & & \\
\hline & g ai ha ${ }^{-1}$ or $L \cdot h a^{-1}$ & & $\%$ & & $\mathrm{~g} \cdot \mathrm{m}^{-1}$ row & $\mathrm{cm}$ & $\%$ & MT ha $^{-1}$ \\
\hline Weed-free check & & 0.0 & 0.0 & 0.0 & 218 & 53.8 & 17.9 & 2.65 \\
\hline Fomesafen & $240 \mathrm{~g}$ & 1.2 & 0.3 & 0.0 & 205 & 53.3 & 17.8 & 2.56 \\
\hline $\begin{array}{c}\text { Fomesafen + Crop } \\
\text { Booster }\end{array}$ & $240 g+2 L$ & 1.8 & 0.3 & 0.0 & 194 & 53.2 & 18.0 & 2.55 \\
\hline $\begin{array}{l}\text { Fomesafen + RR } \\
\text { SoyBooster }\end{array}$ & $240 g+2 L$ & 1.7 & 0.2 & 0.0 & 202 & 54.3 & 18.4 & 2.62 \\
\hline
\end{tabular}

${ }^{\mathrm{a}}$ Significance of contrasts comparing fomesafen alone with fomesafen plus either Crop Booster or RR SoyBooster denoted by ${ }^{*}$ for $\mathrm{P}<0.10$ and ${ }^{* * *}$ for $\mathrm{P}<$ 0.05 beside the respective mean. ${ }^{\mathrm{b}}$ Turbocharge added to all herbicide treatments at $0.5 \% \mathrm{v} / \mathrm{v}$.

Table 6. Comparison of visible cranberry bean injury 1, 2 and 4 WAT, dry weight 4 WAT, height 7 WAT, moisture at harvest and yield for fomesafen alone vs fomesafen plus Crop Booster or RR SoyBooster. Values for the weed-free check were not included in the analysis ${ }^{\mathrm{a}}$.

\begin{tabular}{|c|c|c|c|c|c|c|c|c|}
\hline \multirow{3}{*}{ Treatment $^{\mathrm{b}}$} & \multicolumn{6}{|c|}{ Injury } & \multirow[b]{2}{*}{ Moisture } & \multirow[b]{2}{*}{ Yield } \\
\hline & Rate & $1 \mathrm{WAT}$ & 2 WAT & 4 WAT & Dry weight & Height & & \\
\hline & g ai ha ${ }^{-1}$ or $L \cdot h a^{-1}$ & & $\%$ & & $\mathrm{~g} \cdot \mathrm{m}^{-1}$ row & $\mathrm{cm}$ & $\%$ & MT ha $^{-1}$ \\
\hline Weed-free check & & 0.0 & 0.0 & 0.0 & 231 & 50.1 & 16.6 & 2.40 \\
\hline Fomesafen & $240 \mathrm{~g}$ & 1.2 & 0.3 & 0.0 & 232 & 49.3 & 16.5 & 2.22 \\
\hline Fomesafen + Crop Booster & $240 g+2 L$ & 1.8 & 0.4 & 0.0 & 223 & 49.9 & 16.3 & 2.34 \\
\hline $\begin{array}{c}\text { Fomesafen + RR } \\
\text { SoyBooster }\end{array}$ & $240 g+2 L$ & 1.5 & 0.2 & 0.0 & 231 & 49.6 & 16.8 & 2.26 \\
\hline
\end{tabular}

${ }^{\mathrm{a}}$ Significance of contrasts comparing fomesafen alone with fomesafen plus either Crop Booster or RR SoyBooster denoted by ${ }^{*}$ for $\mathrm{P}<0.10$ and ${ }^{* *}$ for $\mathrm{P}<$ 0.05 beside the respective mean. ${ }^{\mathrm{b}}$ Turbocharge added to all herbicide treatments at $0.5 \% \mathrm{v} / \mathrm{v}$.

At 4 WAT, a $1 \mathrm{~m}$ section of row for each cultivar was hand harvested at the ground level, oven dried at $60^{\circ} \mathrm{C}$ to constant moisture and the shoot dry weight was recorded. Ten plants per plot were randomly selected and the height from the soil surface to the highest growing point was measured 6 WAT. Yield and seed moisture content were measured at crop maturity by combining the remaining $9 \mathrm{~m}$ from each plot at Exeter and $7 \mathrm{~m}$ from each plot at Ridgetown. Crops were considered physically mature when $90 \%$ of pods in the untreated plots of each 
Table 7. Comparison of visible white bean injury 1, 2 and 4 WAT, dry weight 4 WAT, height 7 WAT, moisture at harvest and yield for bentazon + fomesafen alone vs bentazon + fomesafen plus Crop Booster or RR SoyBooster. Values for the weed-free check were not included in the analysis ${ }^{\mathrm{a}}$.

\begin{tabular}{|c|c|c|c|c|c|c|c|c|}
\hline \multirow{3}{*}{ Treatment } & \multicolumn{6}{|c|}{ Injury } & \multirow[b]{2}{*}{ Moisture } & \multirow[b]{2}{*}{ Yield } \\
\hline & Rate & $1 \mathrm{WAT}$ & 2 WAT & 4 WAT & Dry weight & Height & & \\
\hline & g ai ha ${ }^{-1}$ or $\mathrm{L} \cdot \mathrm{ha}^{-1}$ & & $\%$ & & $\mathrm{~g} \cdot \mathrm{m}^{-1}$ row & $\mathrm{cm}$ & $\%$ & MT ha $^{-1}$ \\
\hline Weed-free check & & 0.0 & 0.0 & 0.0 & 218 & 53.8 & 17.9 & 2.65 \\
\hline Bentazon + fomesafen & $840+140 \mathrm{~g}$ & 2.4 & 0.4 & 0.0 & 185 & 53.7 & 18.5 & 2.56 \\
\hline Bentazon + Fomesafen + Crop Booster & $840+140 g+2 L$ & 3.0 & 0.3 & 0.0 & $216^{* *}$ & 54.0 & 18.4 & 2.51 \\
\hline Bentazon + Fomesafen + RR SoyBooster & 840 + $140 \mathrm{~g}+2 \mathrm{~L}$ & 3.6 & 0.1 & 0.0 & 189 & 52.8 & 17.8 & 2.62 \\
\hline
\end{tabular}

${ }^{\mathrm{a} S i g n i f i c a n c e ~ o f ~ c o n t r a s t s ~ c o m p a r i n g ~ b e n t a z o n ~+~ f o m e s a f e n ~ a l o n e ~ w i t h ~ b e n t a z o n ~+~ f o m e s a f e n ~ p l u s ~ e i t h e r ~ C r o p ~ B o o s t e r ~ o r ~ R R ~ S o y B o o s t e r ~ d e n o t e d ~ b y ~}$ for $\mathrm{P}<0.10$ and ${ }^{* *}$ for $\mathrm{P}<0.05$ beside the respective mean.

Table 8. Comparison of visible cranberry bean injury 1, 2 and 4 WAT, dry weight 4 WAT, height 7 WAT, moisture at harvest and yield for bentazon + fomesafen alone vs bentazon + fomesafen plus Crop Booster or RR SoyBooster. Values for the weed-free check were not included in the analysis ${ }^{\mathrm{a}}$.

\begin{tabular}{|c|c|c|c|c|c|c|c|c|}
\hline \multirow{3}{*}{ Treatment } & \multicolumn{6}{|c|}{ Injury } & \multirow[b]{2}{*}{ Moisture } & \multirow[b]{2}{*}{ Yield } \\
\hline & Rate & $1 \mathrm{WAT}$ & 2 WAT & 4 WAT & Dry weight & Height & & \\
\hline & g ai ha ${ }^{-1}$ or $L \cdot h a^{-1}$ & & $\%$ & & $\mathrm{~g} \cdot \mathrm{m}^{-1}$ row & $\mathrm{cm}$ & $\%$ & MT ha $^{-1}$ \\
\hline Weed-free check & & 0.0 & 0.0 & 0.0 & 231 & 50.1 & 16.6 & 2.40 \\
\hline Bentazon + Fomesafen & $840+140 \mathrm{~g}$ & 3.4 & 0.8 & 0.0 & 229 & 48.9 & 16.7 & 2.19 \\
\hline Bentazon + Fomesafen + Crop Booster & $840+140 \mathrm{~g}+2 \mathrm{~L}$ & 3.7 & 0.8 & 0.0 & 244 & 49.9 & 17.0 & 2.16 \\
\hline Bentazon + Fomesafen + RR SoyBooster & $840+140 g+2 L$ & 4.0 & 0.9 & 0.0 & 208 & 49.6 & 16.8 & 2.16 \\
\hline
\end{tabular}

${ }^{\text {a }}$ Significance of contrasts comparing bentazon + fomesafen alone with bentazon + fomesafen plus either Crop Booster or RR SoyBooster denoted by * for $\mathrm{P}<0.10$ and ${ }^{* *}$ for $\mathrm{P}<0.05$ beside the respective mean.

Table 9. Comparison of visible white bean injury 1, 2 and 4 WAT, dry weight 4 WAT, height 7 WAT, moisture at harvest and yield for Imazethapyr alone vs Imazethapyr plus Crop Booster or RR SoyBooster. Values for the weed-free check were not included in the analysis ${ }^{\mathrm{a}}$.

\begin{tabular}{|c|c|c|c|c|c|c|c|c|}
\hline \multirow{3}{*}{ Treatment $^{\mathrm{b}}$} & \multicolumn{6}{|c|}{ Injury } & \multirow[b]{2}{*}{ Moisture } & \multirow[b]{2}{*}{ Yield } \\
\hline & Rate & $1 \mathrm{WAT}$ & $2 \mathrm{WAT}$ & 4 WAT & Dry weight & Height & & \\
\hline & g ai ha ${ }^{-1}$ or $L \cdot h a^{-1}$ & & $\%$ & & $\mathrm{~g} \cdot \mathrm{m}^{-1}$ row & $\mathrm{cm}$ & $\%$ & MT ha \\
\hline Weed-free check & & 0.0 & 0.0 & 0.0 & 218 & 53.8 & 17.9 & 2.65 \\
\hline Imazethapyr + UAN & $75 g+2 L$ & 7.6 & 5.5 & 2.1 & 191 & 53.5 & 18.3 & 2.47 \\
\hline Imazethapyr + Crop Booster & $75 g+2 L$ & 6.5 & 4.9 & 1.7 & 196 & 54.4 & 18.4 & 2.44 \\
\hline $\begin{array}{c}\text { Imazethapyr + RR } \\
\text { SoyBooster }\end{array}$ & $75 g+2 L$ & 7.3 & 5.4 & 2.7 & 192 & 53.9 & 18.9 & 2.36 \\
\hline
\end{tabular}

${ }^{\mathrm{a}}$ Significance of contrasts comparing imazethapyr alone with imazethapyr plus either Crop Booster or RR SoyBooster denoted by ${ }^{*}$ for $\mathrm{P}<0.10$ and ${ }^{* *}$ for $\mathrm{P}<0.05$ beside the respective mean. ${ }^{\mathrm{b}}$ Agral 90 added to all herbicide treatments at $0.25 \% \mathrm{v} / \mathrm{v}$.

cultivar had turned from green to a golden colour. All yields were adjusted to $18 \%$ moisture.

Data for each market class of dry bean (cranberry and white bean) were analyzed as an RCBD using PROC MIXED in SAS 9.2. Herbicide treatment was considered a fixed effect, while environment (year-location combinations), the interaction between environment and herbicide treatment, and replicate nested within environment were considered random effects. Significance of the fixed effect was tested using F-test and random effects were tested using a Z-test of the variance estimate. The UNIVARIATE procedure was used to test data for normality and homogeneity of variance. The untreated check (for injury ratings) was excluded from the analysis. To 
Table 10. Comparison of visible cranberry bean injury 1, 2 and 4 WAT, dry weight 4 WAT, height 7 WAT, moisture at harvest and yield for imazethapyr alone vs imazethapyr plus Crop Booster or RR SoyBooster. Values for the weed-free check were not included in the analysis ${ }^{\mathrm{a}}$.

\begin{tabular}{|c|c|c|c|c|c|c|c|c|}
\hline \multirow{3}{*}{ Treatment $^{\mathrm{b}}$} & \multicolumn{6}{|c|}{ Injury } & \multirow[b]{2}{*}{ Moisture } & \multirow[b]{2}{*}{ Yield } \\
\hline & Rate & 1 WAT & 2 WAT & 4 WAT & Dry weight & Height & & \\
\hline & g ai ha ${ }^{-1}$ or $L \cdot h a^{-1}$ & & $\%$ & & $\mathrm{~g} \cdot \mathrm{m}^{-1}$ row & $\mathrm{cm}$ & $\%$ & MT ha $^{-1}$ \\
\hline Weed-free check & & 0.0 & 0.0 & 0.0 & 231 & 50.1 & 16.6 & 2.40 \\
\hline Imazethapyr + UAN & $75 g+2 L$ & 8.9 & 5.4 & 3.9 & 203 & 51.0 & 20.4 & 2.08 \\
\hline Imazethapyr + Crop Booster & $75 g+2 L$ & 8.6 & 5.5 & 3.3 & 217 & 50.5 & 20.0 & 2.17 \\
\hline $\begin{array}{c}\text { Imazethapyr + RR } \\
\text { SoyBooster }\end{array}$ & $75 g+2 L$ & 9.4 & 5.5 & 3.6 & 208 & 50.1 & 20.6 & 2.05 \\
\hline
\end{tabular}

${ }^{\text {a }}$ Significance of contrasts comparing imazethapyr alone with imazethapyr plus either Crop Booster or RR SoyBooster denoted by ${ }^{*}$ for $\mathrm{P}<0.10$ and ${ }^{* *}$ for $\mathrm{P}<0.05$ beside the respecitive mean. ${ }^{\mathrm{b}}$ Agral 90 added to all herbicide treatments at $0.25 \% \mathrm{v} / \mathrm{v}$.

Table 11. Comparison of visible white bean injury 1, 2 and 4 WAT, dry weight 4 WAT, height 7 WAT, moisture at harvest and yield for Imazethapyr + Bentazon alone vs Imazethapyr + Bentazon plus Crop Booster or RR SoyBooster. Values for the weed-free check were not included in the analysis ${ }^{\mathrm{a}}$.

\begin{tabular}{|c|c|c|c|c|c|c|c|c|}
\hline \multirow{3}{*}{ Treatment } & \multicolumn{6}{|c|}{ Injury } & \multirow[b]{2}{*}{ Moisture } & \multirow[b]{2}{*}{ Yield } \\
\hline & Rate & 1 WAT & 2 WAT & 4 WAT & Dry weight & Height & & \\
\hline & g ai ha ${ }^{-1}$ or L·ha ${ }^{-1}$ & & $\%$ & & $\mathrm{~g} \cdot \mathrm{m}^{-1}$ row & $\mathrm{cm}$ & $\%$ & MT ha $^{-1}$ \\
\hline Weed-free check & & 0.0 & 0.0 & 0.0 & 218 & 53.8 & 17.9 & 2.65 \\
\hline Imazethapyr + Bentazon + UAN & $75+840 \mathrm{~g}+2 \mathrm{~L}$ & 3.6 & 0.9 & 0.6 & 206 & 52.8 & 17.5 & 2.42 \\
\hline Imazethapyr + Bentazon + Crop Booster & $75+840 g+2 L$ & 3.1 & 1.1 & 0.6 & 198 & 53.2 & 17.8 & 2.50 \\
\hline Imazethapyr + Bentazon + RR SoyBooster & 75 + 840 g + $2 L$ & 3.6 & 0.9 & 0.6 & 200 & 53.6 & 17.7 & 2.60 \\
\hline
\end{tabular}

${ }^{\mathrm{a}}$ Significance of contrasts comparing Pursuit + bentazon alone with Pursuit + bentazon plus either Crop Booster or RR SoyBooster denoted by ${ }^{*}$ for P < 0.10 and ${ }^{* *}$ for $\mathrm{P}<0.05$ beside the respective mean.

Table 12. Comparison of visible cranberry bean injury 1, 2 and 4 WAT, dry weight 4 WAT, height 7 WAT, moisture at harvest and yield for imazethapyr + bentazon alone vs imazethapyr + bentazon plus Crop Booster or RR SoyBooster. Values for the weed-free check were not included in the analysis ${ }^{\mathrm{a}}$.

\begin{tabular}{|c|c|c|c|c|c|c|c|c|}
\hline \multirow{3}{*}{ Treatment } & \multicolumn{6}{|c|}{ Injury } & \multirow[b]{2}{*}{ Moisture } & \multirow[b]{2}{*}{ Yield } \\
\hline & Rate & $1 \mathrm{WAT}$ & 2 WAT & 4 WAT & Dry weight & Height & & \\
\hline & g ai ha ${ }^{-1}$ or $L \cdot h a^{-1}$ & & $\%$ & & $\mathrm{~g} \cdot \mathrm{m}^{-1}$ row & $\mathrm{cm}$ & $\%$ & MT ha $^{-1}$ \\
\hline Weed-free check & & 0.0 & 0.0 & 0.0 & 231 & 50.1 & 16.6 & 2.40 \\
\hline Imazethapyr + Bentazon + UAN & $75+840 g+2 L$ & 5.5 & 1.4 & 1.0 & 212 & 49.1 & 16.2 & 2.21 \\
\hline Imazethapyr + Bentazon + Crop Booster & $75+840 g+2 L$ & 5.2 & 1.6 & 0.9 & 220 & 49.4 & 16.4 & 2.20 \\
\hline Imazethapyr + Bentazon + RR SoyBooster & $75+840 g+2 L$ & 5.2 & 1.6 & 1.1 & 206 & 48.9 & 16.4 & 2.22 \\
\hline
\end{tabular}

${ }^{\mathrm{a}}$ Significance of contrasts comparing imazethapyr + bentazon alone with imazethapyr + bentazon plus either Crop Booster or RR SoyBooster denoted by ${ }^{*}$ for $\mathrm{P}<0.10$ and ${ }^{* *}$ for $\mathrm{P}<0.05$ beside the respective mean.

meet assumptions of normality, all injury (except cranberry bean at 4 WAT) were square root transformed; shoot dry weight and seed moisture content were log transformed. Contrasts were used to compare each herbicide versus the same herbicide plus Crop Booster or RR SoyBooster. Data compared on the transformed scale were converted back to the original scale for presentation of results. The Type I error was set at $\mathrm{P}<0.05$ for all statistical comparisons. 


\section{Results and Discussion}

\subsection{Quizalofop-p-ethyl}

White bean visible injury ranged between $0.1 \%$ to $2.2 \%$ with quizalofop-p-ethyl alone, $0 \%$ to $2.5 \%$ with quizalofop-p-ethyl plus Crop Booster and $0 \%$ to $2.1 \%$ with quizalofop-p-ethyl plus RR SoyBooster at 1, 2 and 4 WAT (Table 1). Visible injury decreased over time for all herbicide tankmixes, however, there were no significant differences in visible injury among treatments evaluated. The addition of Crop Booster to quizalofopp-ethyl had no significant effect on white bean shoot dry weight, height, seed moisture content and yield. The addition of RR SoyBooster to quizalofop-p-ethyl increased white bean height 3.7\% but had no significant effect on white bean shoot dry weight, seed moisture content and yield (Table 1).

Cranberry bean visible injury ranged between $0.2 \%$ to $2.1 \%$ with quizalofop-p-ethyl alone, $0.3 \%$ to $2.4 \%$ with quizalofop-p-ethyl plus Crop Booster and $0.2 \%$ to $2.3 \%$ with quizalofop-p-ethyl plus RR SoyBooster at 1 , 2 and 4 WAT (Table 2). Visible injury decreased over time for all herbicide tankmixes, however, there were no significant differences in visible injury among treatments evaluated. The addition of Crop Booster or RR SoyBooster to quizalofop-p-ethyl had no significant effect on cranberry bean shoot dry weight, height, seed moisture content and yield.

Results are similar to other studies that have shown quizalofop-p-ethyl causes minimal injury in dry bean [14]-[16].

\subsection{Bentazon}

White bean visible injury ranged between $0 \%$ to $1.9 \%$ with bentazon, $0 \%$ to $2.4 \%$ with bentazon plus Crop Booster and $0 \%$ to $2.9 \%$ with bentazon plus RR SoyBooster at 1 , 2 and 4 WAT (Table 3). Visible injury decreased over time for all herbicide tankmixes, however, there were no significant differences in visible injury among treatments evaluated. The addition of Crop Booster to bentazon decreased shoot dry weight $12 \%$ but had no significant effect on white bean height, seed moisture content and yield. The addition of RR SoyBooster to bentazon had no significant effect on white bean shoot dry weight, height, seed moisture content and yield.

Cranberry bean visible injury ranged between $0 \%$ to $2.8 \%$ with bentazon alone, $0 \%$ to $3.4 \%$ with bentazon plus Crop Booster and 0\% to 3.5\% with bentazon plus RR SoyBooster at 1, 2 and 4 WAT (Table 4). Visible injury decreased over time for all herbicide tankmixes, however, there were no significant differences in visible injury among treatments evaluated. The addition of Crop Booster or RR SoyBooster to bentazon had no significant effect on shoot dry weight, height, seed moisture content and yield of cranberry bean. Results are similar to other studies which have shown less than $3 \%$ visual injury with no adverse effect on plant height or yield of black and cranberry bean with the post-emergence application of bentazon at $1080 \mathrm{~g} \cdot \mathrm{ha}^{-1}$ [15]. However, other studies have found as much as $8 \%$ injury with bentazon applied POST in dry bean [17].

\subsection{Fomesafen}

White bean visible injury ranged between $0 \%$ to $1.2 \%$ with fomesafen, $0 \%$ to $1.8 \%$ with fomesafen plus Crop Booster and $0 \%$ to $1.7 \%$ with fomesafen plus RR SoyBooster at 1,2 and 4 WAT (Table 5). Visible injury decreased over time for all herbicide tankmixes, however, there were no significant differences in visible injury among treatments evaluated. The addition of Crop Booster or RR SoyBooster to fomesafen had no significant effect on white bean shoot dry weight, height, seed moisture content and yield.

Cranberry bean visible injury ranged between $0 \%$ to $1.2 \%$ with fomesafen alone, $0 \%$ to $1.8 \%$ with fomesafen plus Crop Booster and 0 to 1.5\% with fomesafen plus RR SoyBooster at 1, 2 and 4 WAT (Table 6). Visible injury decreased over time for all herbicide tankmixes, however, there were no significant differences in visible injury among treatments evaluated. The addition of Crop Booster or RR SoyBooster to fomesafen had no significant effect on shoot dry weight, height, seed moisture content and yield of cranberry bean. Results are similar to other studies that have reported minimal injury with fomesafen applied POST alone or in tank mix with other herbicides in dry bean [15].

\subsection{Bentazon plus Fomesafen}

White bean visible injury ranged between $0 \%$ to $2.4 \%$ with bentazon plus fomesafen, $0 \%$ to $3.0 \%$ with bentazon 
plus fomesafen plus Crop Booster and $0 \%$ to 3.6\% with bentazon plus fomesafen plus RR SoyBooster at 1, 2 and 4 WAT (Table 7). Visible injury decreased over time for all herbicide tankmixes, however, there were no significant differences in visible injury among treatments evaluated. The addition of Crop Booster to bentazon plus fomesafen increased shoot dry weight $17 \%$ but had no significant effect on white bean height, seed moisture content and yield. The addition of RR SoyBooster to bentazon plus fomesafen had no significant effect on shoot dry weight, height, seed moisture content and yield of white bean.

Cranberry bean visible injury ranged between $0 \%$ to $3.4 \%$ with bentazon plus fomesafen alone, $0 \%$ to $3.7 \%$ with bentazon plus fomesafen plus Crop Booster and 0\% to 4.0\% with bentazon plus fomesafen plus RR SoyBooster at 1, 2 and 4 WAT (Table 8). Visible injury decreased over time for all herbicide tankmixes, however, there were no significant differences in visible injury among treatments evaluated. The addition of Crop Booster or RR SoyBooster to bentazon plus fomesafen had no significant effect on cranberry bean shoot dry weight, height, seed moisture content and yield. Results are similar to other studies in which bentazon plus fomesafen caused $0.7 \%$ to $3 \%$ injury with no adverse effect on height, shoot dry weight and yield in dry beans [18].

\subsection{Imazethapyr}

White bean visible injury ranged between $2.1 \%$ to $7.6 \%$ with imazethapyr, $1.7 \%$ to $6.5 \%$ with imazethapyr plus Crop Booster and 2.7\% to 7.3\% with imazethapyr plus RR SoyBooster at 1, 2 and 4 WAT (Table 9). Visible injury decreased over time for all herbicide tankmixes, however, there were no significant differences in visible injury among treatments evaluated. The addition of Crop Booster or RR SoyBooster to imazethapyr had no significant effect on white bean shoot dry weight, height, seed moisture content and yield.

Cranberry bean visible injury ranged between $3.9 \%$ and $8.9 \%$ with imazethapyr alone, $3.3 \%$ to $8.6 \%$ with imazethapyr plus Crop Booster and 3.6\% to 9.4\% with imazethapyr plus RR SoyBooster at 1, 2 and 4 WAT (Table 10). Visible injury decreased over time for all herbicide tankmixes, however, there were no significant differences in visible injury among treatments evaluated. The addition of Crop Booster or RR SoyBooster to imazethapyr had no significant effect on shoot dry weight, height, seed moisture content and yield of cranberry bean. Results are in contrast with other studies that have shown that imazethapyr applied POST at 70 to $100 \mathrm{~g}$ ai ha $^{-1}$ caused up to 20\% injury in dry bean [19] [20]. Renner and Powell [21] also reported that imazethapyr applied POST caused 20\% injury in pinto bean. However, other studies conducted in New Mexico and Alberta have shown that imazethapyr applied POST at 50 and $70 \mathrm{~g}$ ai ha ${ }^{-1}$ causes minimal injury in pinto bean [22] [23].

\subsection{Imazethapyr plus Bentazon}

White bean visible injury ranged between $0.6 \%$ to $3.6 \%$ with imazethapyr plus bentazon, $0.6 \%$ to $3.1 \%$ with imazethapyr plus bentazon plus Crop Booster and 0.6\% to 3.6\% with imazethapyr plus bentazon plus RR SoyBooster at 1, 2 and 4 WAT (Table 11). Visible injury decreased over time for all herbicide tankmixes, however, there were no significant differences in visible injury among treatments evaluated. The addition of Crop Booster or RR SoyBooster to imazethapyr plus bentazon had no significant effect on shoot dry weight, height, seed moisture content and yield of white bean.

Cranberry bean visible injury ranged between $1.0 \%$ to $5.5 \%$ with imazethapyr plus bentazon, $0.9 \%$ to $5.2 \%$ with imazethapyr plus bentazon plus Crop Booster and $1.1 \%$ to $5.2 \%$ with imazethapyr plus bentazon plus RR SoyBooster at 1, 2 and 4 WAT (Table 12). Visible injury decreased over time for all herbicide tankmixes, however, there were no significant differences in visible injury among treatments evaluated. The addition of Crop Booster or RR SoyBooster to imazethapyr plus bentazon had no significant effect on shoot dry weight, height, seed moisture content and yield of cranberry bean.

Injury with imazethapyr plus bentazon was less than imazethapyr alone in white and cranberry bean which was similar to other studies that had shown that imazethapyr plus bentazon (53 $\mathrm{g}$ ai ha ${ }^{-1}$ plus $840 \mathrm{~g}$ ai ha ${ }^{-1}$ ) applied POST reduced pinto bean injury by up to 5\% compared to imazethapyr alone [19].

\section{Conclusion}

Based on these results, there was no increase in visible injury with the addition of Crop Booster or RR SoyBooster to quizalofop-p-ethyl, bentazon, fomesafen, bentazon plus fomesafen, imazethapyr and imazethapyr plus bentazon in cranberry and white bean under Ontario environmental conditions. The addition of Crop 
Booster or RR SoyBooster to quizalofop-p-ethyl, bentazon, fomesafen, bentazon plus fomesafen, imazethapyr and imazethapyr plus bentazon generally had no effect on shoot dry weight, plant height, seed moisture content of cranberry or white bean. In many comparisons, there was a small numeric increase in yield of white and cranberry bean with the addition of Crop Booster or RR SoyBooster to quizalofop-p-ethyl, bentazon, fomesafen and bentazon plus fomesafen, but this increase in yield was not statistically significant at the $\mathrm{P}<0.05$ level.

\section{Acknowledgements}

The authors would like to acknowledge Todd Cowan for his expertise and technical assistance in these studies.

\section{References}

[1] Ontario Bean Growers (2014) Canadian Bean Production in 2014. http://ontariobeans.on.ca/canadian-bean-production-in-2014/

[2] European Biostimulant Industry Council, EBIC (2012) http://www.biostimulants.eu/

[3] Calvo, P., Nelson, L. and Kloepper, J.W. (2014) Agricultural Uses of Plant Biostimulants. Plant and Soil, 383, 3-41. http://dx.doi.org/10.1007/s11104-014-2131-8

[4] Shekhar Sharma, H.S., Fleming, C., Selby, C., Rao, J.R. and Martin, T. (2014) Plant Biostimulants: A Review on the Processing of Macroalgae and Use of Extracts for Crop Management to Reduce Abiotic and Biotic Stresses. Journal of Applied Phycology, 26, 465-490. http://dx.doi.org/10.1007/s10811-013-0101-9

[5] Khan, W., Rayorath, U.P., Subramanian, S., Jithesh, M.N., Rayorath, P., Hodges, D.M., Critchley, A.T., Craigie, J.S., Norrie, J. and Prithiviraj, B. (2009) Seaweed Extracts as Biostimulants of Plant Growth and Development. Journal of Plant Growth Regulation, 28, 386-399. http://dx.doi.org/10.1007/s00344-009-9103-X

[6] Sanderson, K.J., Jameson, P.E. and Zabkiewicz, J.A. (1987) Auxin in a Seaweed Extract: Identification and Quantitation of Indole-3-acetic Acid by Gas Chromatography-Mass Spectrometry. Journal of Plant Physiology, 129, 363-367. http://dx.doi.org/10.1016/S0176-1617(87)80093-7

[7] Hanson, K.R. (1988) Plant Nutritional Activators Increase Vegetable Yield. Citrus and Vegetable Magazine, 7, 10-12.

[8] Chapman, V.J. and Chapman, D.J. (1980) Seaweeds and Their Uses, 3rd Edition, Chapman and Hall, Ltd., London.

[9] Redmond, S. (2009) Crop Growth Promoting Products on Soys/Corn/Wheat. Crop Advances: Field Crop Reports 2009, 1-2. http://www.ontariosoilcrop.org/docs/v6gen3.pdf

[10] Al Majathoub, M. (2004) Effect of Biostimulants on Production of Wheat (Triticum aestivum L.). In: Cantero-Martínez, C. and Gabiña, D., Ed., Mediterranean Rainfed Agriculture: Strategies for Sustainability, CIHEAM, Zaragoza, 147 -150 .

[11] Axter Agrosciences Inc. (2015) Fact Sheet-Biostimulant: Crop Booster. http://www.axter.ca/wp-content/uploads/2015/04/Crop-Booster_Fiche-Produit-ANG_March-2015.pdf

[12] Axter Agrosciences Inc. (2015) Label: Crop Booster. http://www.axter.ca/wp-content/uploads/2015/04/Crop-Booster Etiquette-ANG March-2015vf.pdf

[13] Axter Agrosciences Inc. (2015) Label: Soy Booster. http://www.axter.ca/wp-content/uploads/2015/04/RR-Soy-Booster_Etiquette-ANG_Mars-2015.pdf

[14] Van Gessel, J.M., Monks, W.D. and Quintin, R.J. (2000). Herbicides for Potential Use in Lima Bean (Phaseolus lunatus) Production. Weed Technology, 14, 279-286. http://dx.doi.org/10.1614/0890-037X(2000)014[0279:HFPUIL]2.0.CO;2

[15] Soltani, N., Bowley, S. and Sikkema, P.H. (2005) Responses of Black and Cranberry Beans (Phaseolus vulgaris) to Postemergence Herbicides. Crop Protection, 24, 15-21. http://dx.doi.org/10.1016/j.cropro.2004.06.003

[16] Sikkema, P.H., Soltani, N., Shropshire, C. and Cowan, T. (2004) Tolerance of White Beans to Postemergence Broadleaf Herbicides. Weed Technology, 18, 893-901. http://dx.doi.org/10.1614/WT-03-043R3

[17] Wall, D.A. (1995) Bentazon Tank-Mixtures for Improved Redwood Pigweed (Amaranthus retroflexus) and Common Lambsquarters (Chenopodium album) Control in Navy Beans (Phaseolus vulgaris). Weed Technology, 9, 610-616.

[18] Soltani, N., Shropshire, C. and Sikkema, P.H. (2006) Effects of Post-Emergence Application of Bentazon and Fomesafen on Eight Market Classes of Dry Beans (Phaseolus vulgaris L.) Crop Protection, 25, 826-830. http://dx.doi.org/10.1016/j.cropro.2005.11.011

[19] Bauer, T.A., Renner, K.A., Penner, D. and Kelly, J.D. (1995). Pinto Bean (Phaseolus vulgaris) Varietal Tolerance to Imazethapyr. Weed Science, 43, 417-424.

[20] Wilson, R.G. and Miller, S.D. (1991) Dry Edible Bean (Phaseolus vulgaris) Responses to Imazethapyr. Weed Tech- 
nology, 5, 22-26.

[21] Renner, K.A. and Powell, G.E. (1992) Responses of Navy Bean (Phaseolus vulgaris) and Wheat (Triticum aestivum) Grown in Rotation to Clomazone, Imazethapyr, Bentazon, and Acifluorfen. Weed Science, 40, 127-133.

[22] Arnold, N.R., Murray, W.M., Gregory, J.E. and Smeal, D. (1993) Weed Control in Pinto Beans (Phaseolus vulgaris) with Imazethapyr Combinations. Weed Technology, 7, 361-364.

[23] Blackshaw, R.E. and Esau, R. (1991) Control of Annual Broadleaved Weeds in Pinto Beans (Phaseolus vulgaris). Weed Technology, 5, 532-538.

\section{Abbreviation}

WAT: weeks after herbicide treatment. 